\title{
Epidermal Growth Factor Promotes Proliferation and Migration of Follicular Outer Root Sheath Cells via Wnt/ $\beta$-Catenin Signaling
}

\author{
Haihua Zhang ${ }^{a}$ Weixiao Nan ${ }^{b}$ Shiyong Wang ${ }^{a}$ Tietao Zhang ${ }^{a}$ Huazhe Sib \\ Fuhe Yang ${ }^{\mathrm{a}}$ Guangyu $\mathrm{Li}^{\mathrm{a}}$ \\ aInstitute of Special Animal and Plant Sciences, Chinese Academy of Agricultural Sciences, State Key \\ Laboratory for Molecular Biology of Special Economic Animals, Changchun, ${ }^{b}$ College of Animal Science \\ and Technology, Jilin Agricultural University, Changchun, People's Republic of China
}

\section{Key Words}

Epidermal growth factor - Outer root sheath - Proliferation - Migration - Wnt/ß-catenin signaling

\begin{abstract}
Background/Aims: To investigate the effect and molecular mechanism of EGF on the growth and migration of hair follicle outer root sheath (ORS) cells. Methods: Intact anagen hair follicles were isolated from mink skin and cultured with EGF in vitro to measure ORS daily growth. Meanwhile, purified primary ORS cells were treated or transfected with EGF, and their proliferation and migration were assessed by MTT assay and transwell assay, respectively. The signaling pathway downstream of EGF was characterized by using the $\mathrm{Wnt} / \beta$-catenin signaling inhibitor, XAV-939. Results: EGF of 2-20 ng/ml, not higher or lower, promoted the growth of follicular ORS in vitro. EGF treatment or overexpression promoted the proliferation and migration of ORS cells. Moreover, EGF stimulation induced nuclear translocation of $\beta$-catenin, and upregulated the expression of Wnt10b, $\beta$-catenin, EGF receptor and SOX9. Inhibition of Wnt/ $\beta$-catenin signaling by XAV-939 significantly reduced the basal and EGF-enhanced proliferation and migration of ORS cells. In addition, a number of follicle-regulatory genes, such as Survivin, Msx2 and SGK3, were upregulated by EGF in the ORS cells, which was also inhibited by XAV-939. Conclusion: EGF promotes the proliferation and migration of ORS cells and modulates the expression of several follicle-regulatory genes via $\mathrm{Wnt} / \beta$-catenin signaling.

\section{Introduction}

The hair follicle consists of several concentric cylinders of epithelial cells that surround the hair shaft, including the inner root sheath (IRS) - the most inner layer, and the outer root 


\section{Cellular Physiology Cell Physiol Biochem 2016;39:360-370 \\ \begin{tabular}{l|l} 
and Biochemistry Published online: June 29, 2016 & $\begin{array}{l}\text { (c) 2016 The Author(s). Published by S. Karger AG, Basel } \\
\text { www.karger.com/cpb }\end{array}$
\end{tabular} \\ Zhang et al.: EGF Promotes ORS Growth and Migration via Wnt/ $\beta$-Catenin}

sheath (ORS) - the outermost layer. In the mature hair follicles, the ORS, composed of nonkeratinized epithelial cells, extends from the base of the follicle bulb to the piliary canal, and is contiguous to the basal layer of the epidermis [1]. As a connecting component between the hair follicle and the epidermis, the ORS plays an essential role in the development and maintenance of the hair follicle and the growth of the hair shaft [2]. The hair and hair follicle undergo cyclic growth through three phases: anagen (growth), catagen (regression) and telogen (inactivity). The ORS represents a highly proliferative compartment in the follicle during the anagen phase.

EGF was first identified as a potent modulator of cell growth and differentiation in skin [3]. Histological studies revealed that EGF receptors (EGFR) were widely distributed in the epidermis and the epidermal derivatives of the cutaneous appendages, and were particularly localized in the sebaceous glands and over the ORS of the anagen hair bulb [4, 5]. Moreover, a temporary downregulation of EGFR in the basal epidermis was observed prior to follicle initiation during the embryonic development of sheep or rat $[4,5]$. These observations demonstrated a dynamic expression of EGFR during the initiation and cyclic growth of hair follicles, suggesting a spatiotemporal regulation of EGF signaling in follicle development and growth. Previous studies have shown that EGF can stimulate a mitogenic response in ORS cells in vitro and in vivo $[6,7]$, yet the underlying mechanism remains elusive.

The morphogenesis and development of the hair follicle depends on a number of signaling pathways [8]. The Wnt/ $\beta$-catenin signaling pathway is considered as the master regulator during hair follicle morphogenesis because loss of function of $\beta$-catenin, an essential signal transducer in Wnt signaling pathway, blocks the formation of placodes and the subsequent generation of hair follicles during embryogenesis [9]. Moreover, deletion of $\beta$-catenin after hair follicles have formed leads to complete hair loss after the first hair cycle [9], suggesting a crucial role of Wnt signaling in the maintenance of the postnatal hair cycle. The Wnt ligands, on the other hand, are classified as primary Wnts (Wnts 3, 4 and 6) and secondary Wnts (Wnts 2, 7b, 10a and 10b) based on the current functional evidences. The primary Wnts are essential players during the initiation of hair follicles, while the secondary Wnts are involved in the development of hair follicles [8, 10, 11].

In the present study, the effects of EGF on the growth of ORS, as well as the proliferation and migration of ORS cells were assessed using anagen hair follicles and primary ORS cells from American minks. Furthermore, the role of the Wnt/ $\beta$-catenin signaling pathway in EGF-modulated cellular activities was also investigated. Our study demonstrates that EGF promotes proliferation and migration of ORS cells, and upregulates the expression of several follicle-regulatory genes via the $\mathrm{Wnt} / \beta$-catenin signaling pathway.

\section{Materials and Methods}

\section{Isolation and culture of hair follicles and ORS cells}

The experiment was performed at the Teaching and Research Farm of the Institute of Special Economic Animal and Plant Science of Chinese Academy Agricultural Sciences (Jilin, China). Hair follicles were obtained from 4-month old, male Neovison vison (American mink). Small pieces $\left(1 \mathrm{~cm}^{2}\right)$ of the dorsal skin were surgically excised, and the hair shafts and subcutaneous fat were removed. Following rinsing with sterile PBS (containing $100 \mathrm{U} / \mathrm{ml}$ penicillin and $0.1 \mathrm{mg} / \mathrm{ml}$ streptomycin), the skin specimens were disinfected with iodine and destained with $75 \%$ ethanol. Subsequently, the skin tissues were digested with $0.2 \mathrm{mg} / \mathrm{ml}$ collagenase D (Sigma-Aldrich, St. Louis, MO, USA) overnight at $4^{\circ} \mathrm{C}$. After digestion, the hair follicles were carefully pulled out of skin individually with forceps under a microscope. Excess hair shaft outside the follicle was cut off, and the intact follicles were cultured in Williams E medium (Gibco, Carlsbad, CA, USA) supplemented with $10 \mu \mathrm{g} / \mathrm{ml}$ insulin, $10 \mu \mathrm{g} / \mathrm{ml}$ transferrin, $10 \mathrm{ng} / \mathrm{ml}$ hydrocortisone, $10 \mathrm{ng} / \mathrm{ml}$ sodium selenite, $2 \mathrm{mM}$ L-glutamine, $100 \mathrm{U} / \mathrm{ml}$ penicillin and $0.1 \mathrm{mg} / \mathrm{ml}$ streptomycin (all from Sigma-Aldrich). The follicles were treated with EGF (Sino Biological Inc., Beijing, China) at $0.2 \mathrm{ng} / \mathrm{ml}, 2 \mathrm{ng} /$ $\mathrm{ml}, 20 \mathrm{ng} / \mathrm{ml}$ or $200 \mathrm{ng} / \mathrm{ml}$, and maintained at $37^{\circ} \mathrm{C}$ in a humidified atmosphere consisting of $95 \%$ air and $5 \% \mathrm{CO}_{2}$. The medium was changed every 2 days. The length of the ORS was measured every day from the 


\section{Cellular Physiology Cell Physiol Biochem 2016;39:360-370 \begin{tabular}{cc|c} 
DOI: 10.1159/000445630 & $\begin{array}{l}\text { O 2016 The Author(s). Published by S. Karger AG, Basel } \\
\text { wwww.karger.com/cpb }\end{array}$
\end{tabular} \\ Zhang et al.: EGF Promotes ORS Growth and Migration via Wnt/ $/$-Catenin}

beginning of culture (Day 0) till Day 6. Daily growth of the ORS was determined by the length difference of two consecutive days, and the total growth was the length difference between Day 6 and Day 0 .

\section{Isolation and culture of ORS cells}

The ORS culture was established based on a previously reported method [12]. Briefly, intact hair follicles were collected as described above, and the follicles were aligned evenly in a $35 \mathrm{~mm}^{2}$ culture dish and cultured in DMEM (Gibco) supplemented with 10\% fetal bovine serum (FBS) (Gibco) in a humidified atmosphere of $5 \% \mathrm{CO}_{2}$. The ORS cells gradually attached to the culture dish. The medium was changed every three days, and the cells at passage 3 were used in subsequent experiments. The cultured ORS cells were identified by the expression of cytokeratin 19 (CK19) using rabbit anti-CK19 polyclonal antibody (\#BA2266-1, BOSTER, Wuhan, China) by immunefluorescence staining and by immunocycochemistry with a StreptAvidin Biotin Complex (SABC) kit (BOSTER).

For EGF treatment, the cells were cultured with EGF at a concentration of $25 \mathrm{ng} / \mathrm{ml}$ or $50 \mathrm{ng} / \mathrm{ml}$ or 100 $\mathrm{ng} / \mathrm{ml}$ for $48 \mathrm{~h}$, followed by real-time PCR and Western blot analysis. For inhibition of the $\beta$-catenin pathway, $10 \mu \mathrm{M}$ XAV-939 (MedChem Express, NJ, USA) was added into the culture $4 \mathrm{~h}$ prior to addition of $50 \mathrm{ng} / \mathrm{ml}$ EGF or $4 \mathrm{~h}$ after transfection.

\section{Transfection}

The plasmid encoding the open reading frame of murine EGF, pCMV3-mEGF (\# MG50482-UT), and the control vector pCMV3-untagged (\#CV011) were purchased from Sino Biological Inc. ORS cells were plated in 6-well plates at $3 \times 10^{5}$ cells/well or in 96-well plates at 4,000 cells/well, and cultured for $24 \mathrm{~h}$. The cells were incubated with serum-free DMEM for $1 \mathrm{~h}$, followed by transfection with the EGF overexpression plasmids (EGF O/E) or the control vector using Lipofectamine LTX (Invitrogen, Carlsbad, CA, USA) according to the manufacturer's instructions. The medium was replaced with fresh culture medium $4 \mathrm{~h}$ later.

\section{Proliferation/MTT assay}

ORS cells were plated in 96-well plates at a density of 4,000 cells per well and cultured for $24 \mathrm{~h}$. The cells were then subjected to transfection and/or the indicated treatment, and MTT solution (Sigma) was added to the cells $12 \mathrm{~h}, 24 \mathrm{~h}$ or $48 \mathrm{~h}$ later for $4 \mathrm{~h}$ incubation at $37^{\circ} \mathrm{C}$. Formazan crystals were solubilized with $200 \mu \mathrm{l}$ DMSO per well and the optical density (OD) at $490 \mathrm{~nm}$ was measured with an ELX-800 microplate reader (Bio-Tek Instruments, Winooski, VT, USA). Each assay point was done in five replicates.

\section{Migration assay}

Migration of the ORS cells was measured in the transwell apparatus (Corning, NY, USA) $24 \mathrm{~h}$ after EGF treatment or transfection. ORS cells in suspension $\left(1 \times 10^{4}\right.$ cells/200 $\left.\mu \mathrm{l}\right)$ with or without EGF and/or XAV-939 were added to the upper chamber, and $800 \mu \mathrm{l}$ of culture medium containing $20 \%$ FBS was added to the lower chamber. After $24 \mathrm{~h}$, the cells on the upper surface of the transwell membrane were carefully wiped off, and the membrane was fixed with $4 \%$ paraformaldehyde and stained with $0.5 \%$ crystal violet (Amresco, Solon, OH, USA). The cells on the bottom surface of the membrane were examined under an inverted microscope at 200 $\times$ magnification, and the number of migrated cells was presented as the mean of the cell numbers in 5 random fields on each membrane.

\section{Real-time PCR}

Total RNAs were extracted using the RNApure Total RNA Extraction Kit (BioTeke, Beijing, China). Reverse transcription was performed using Super M-MLV reverse transcriptase (\#PR6502, BioTeke) at $42^{\circ} \mathrm{C}$ for $1 \mathrm{~h}$. Real time-PCR analysis was conducted with the SYBR Green I Master Mix (Solarbio, Beijing, China) and the primers are listed in Table 1. The real-time fluorescence signals were detected by the Exicycler 96 Quantitative PCR Analyzer (BIONEER, Daejeon, Korea). Actb, encoding $\beta$-actin, was used as the internal reference.

\section{Western blot analysis}

Total proteins were extracted with the Total Protein Extraction Kit (\#WLA019, Wanleibio, Shenyang, China); nuclear and cytosolic proteins were extracted with the Nuclear and Cytosolic Protien Extraction Kit (\#WLA020, Wanleibio). The protein concentration was determined with a BCA Assay Kit (Wanleibio). Forty 


\begin{tabular}{|c|c|c|}
\hline Cellular Physiology & Cell Physiol Biochem 2016; & 9:360-370 \\
\hline hemistry & $\begin{array}{l}\text { DOI: } 10.11159 / 000445630 \\
\text { Published online: June } 29,2016\end{array}$ & $\begin{array}{l}\text { O } 2016 \text { The Author(s). Published by S. Karger AG, Basel } \\
\text { www.karger.com/cpb }\end{array}$ \\
\hline
\end{tabular}

Table 1. Primer sequences for quantitative real-time PCR

\begin{tabular}{lll}
\hline Gene name & Forward & Reverse \\
\hline EGF & 5'-ACTCCCACCTACCCTCCTA-3' & 5'-CTGAACTGGCTCTGTCTGC-3' \\
EGFR & 5'-GCCTGATAACTGGACTGACCT-3' & 5'-ATTGGGTGTCCCGAAGAGT-3' \\
Sox9 & 5'-ACCAGTACCCGCATCTGCA -3' & 5'-TGTTCCGTGGCCTCTTCG -3' \\
CTNNB1 & 5'-TGTTCCGTGGCCTCTTCG-3' & 5'-GGATGAGCAGCGTCAAACT-3' \\
SGK3 & 5'-ATCTTCTTACCATAGCGTCCT-3' & 5'-GCCTCTTCTACCACCTTACCA-3' \\
Survivin & 5'-TTCACTGGCAAACACTATACCT-3' & 5'-CTCCTCCTGACAGCAAACC-3' \\
Msx2 & 5'-CCGCCTGTTGGACTCTATG-3' & 5'-AGTTGGCACCACCTTCTCG-3' \\
Actb & 5'-CTGTGCCCATCTACGAGGGCTAT-3' & 5'-TTTGATGTCACGCACGATTTCC-3' \\
\hline
\end{tabular}

$\mu \mathrm{g}$ proteins from each sample were separated by SDS-PAGE, and then transferred onto PVDF membranes (Millipore, Bedford, MA, USA). The membranes were blocked with 5\% non-fat milk solution for $1 \mathrm{~h}$ at room temperature, and incubated overnight at $4{ }^{\circ} \mathrm{C}$ with one of the following primary antibodies: rabbit polyclonal anti-EGF (1:400; \#BA4741, BOSTER), rabbit monoclonal anti-EGFR (1:1000; \#ab52894, abcam, Cambridge, UK), rabbit polyclonal anti-SOX9 (1:500; bs-10725R, Bioss, Beijing, China), rabbit polyclonal anti- $\beta$-catenin (1:400; \#BA0426, BOSTER), rabbit polyclonal anti-Wnt10b (1:500; \#bs-3662R, Bioss), rabbit polyclonal anti-SGK3 (1:500; \#bs-6475R, Bioss), rabbit polyclonal anti-Survivin (1:400; \#PB0377, BOSTER), and rabbit polyclonal anti-Msx2 (1:500; \#bs-10158R, Bioss). After washing with TBST for 5 min thrice, the blots were incubated with horseradish peroxidase-conjugated goat anti-rabbit IgG antibodies (1:5000; \#WLA023, Wanleibio) for $45 \mathrm{~min}$ at room temperature. The signals were visualized with the chemiluminescence detection system (Wanleibio). The blots were stripped with the stripping buffer and re-probed for the internal reference protein: $\beta$-actin (mouse monoclonal anti- $\beta$-actin, \#sc-47778, Santa Cruz, Dallas, TX, USA) for total and cytosolic proteins, and Histone H3 (rabbit polyclonal anti-Histone H3, \#bs-17422R, Bioss) for nuclear proteins.

\section{Immunofluorescent staining}

The cells were fixed with $4 \%$ paraformaldehyde for $15 \mathrm{~min}$, washed with PBS, permeabilized with $0.1 \%$ Triton X-100 for $30 \mathrm{~min}$ at room temperature, blocked with goat serum and incubated with rabbit polyclonal anti- $\beta$-catenin antibody (1:200; \#BA0426, BOSTER) at $4^{\circ} \mathrm{C}$ overnight. After washing with PBS, the cells were incubated with Cy3-labeled goat anti-rabbit secondary antibody (1:200; \#A0516, Beyotime, Haimen, China) for $1 \mathrm{~h}$ at room temperature in the dark. The cell nuclei were counter-stained with DAPI (Biosharp, Hefei, China), and the cells were observed by fluorescence microscopy (BX53, OLYMPUS, Japan).

\section{Statistical analysis}

All in vitro assays were repeated in three independent experiments. The data were analyzed with the SPSS software (IBM, USA), and the values are expressed as means \pm standard deviation (SD). Homogeneity of variance was first tested, and the significance of difference between multiple groups was evaluated by one-way ANOVA, followed by Bonferroni post-hoc test. $p<0.05$ is considered statistically significant.

\section{Results}

\section{EGF modulates ORS growth in vitro}

Mink hair follicles were isolated and cultured in vitro in the presence of EGF ranging from 0.2 to $200 \mathrm{ng} / \mathrm{ml}$. The length of the ORS was measured every day, and the daily growth of the ORS was recorded. As shown in Table 2, for all hair follicles, the ORS grew fastest on the first day of culture, and the growth rate gradually declined in the following days. A low concentration of EGF $(0.2 \mathrm{ng} / \mathrm{ml})$ did not affect the growth of the ORS during $6 \mathrm{~d}$ culture. By contrast, EGF of $2 \mathrm{ng} / \mathrm{ml}$ and $20 \mathrm{ng} / \mathrm{ml}$ significantly enhanced ORS elongation in the first few days, and led to a marked total growth of the ORS over 6 days of culture. Notably, EGF of a higher concentration $(200 \mathrm{ng} / \mathrm{ml})$ did not stimulate ORS growth as $2-20 \mathrm{ng} / \mathrm{ml}$ EGF did. 


\section{Cellular Physiology Cell Physiol Biochem 2016;39:360-370

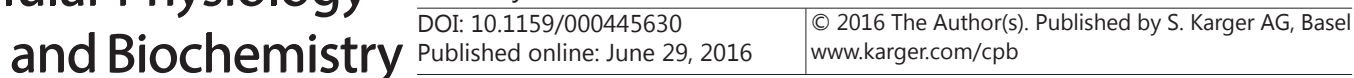 \\ Zhang et al.: EGF Promotes ORS Growth and Migration via Wnt/ $\beta$-Catenin}

Table 2. Growth of the follicular ORS with EGF treatment. Note: compared with ORS growth of the untreated hair follicles on the same day, ${ }^{*} p<0.05,{ }^{* *} p<0.01,{ }^{* * *} p<0.001$

\begin{tabular}{llllllll}
\hline $\begin{array}{l}\text { EGF } \\
(\mathrm{ng} / \mathrm{ml})\end{array}$ & Day 1 & Day 2 & Day 3 & Day 4 & Day 5 & Day 6 & \multicolumn{2}{l}{ Total growth } \\
\hline 0 & $3.6 \pm 0.71$ & $2.09 \pm 0.68$ & $1.93 \pm 0.73$ & $1.67 \pm 0.31$ & $1.39 \pm 0.27$ & $1.58 \pm 0.26$ & $12.27 \pm 0.73$ \\
0.2 & $3.16 \pm 0.87$ & $2.87 \pm 0.54$ & $2.37 \pm 0.44$ & $1.77 \pm 0.58$ & $1.79 \pm 0.54$ & $1.38 \pm 0.35$ & $13.32 \pm 1.09$ \\
2 & $4.02 \pm 0.64$ & $3.3 \pm 0.34^{* *}$ & $3.14 \pm 0.82^{* *}$ & $2.68 \pm 0.46^{*}$ & $1.83 \pm 0.34$ & $2.01 \pm 0.2$ & $16.99 \pm 1.23^{* * *}$ \\
20 & $4.82 \pm 0.56^{* *}$ & $5.13 \pm 0.68^{* * *}$ & $3.96 \pm 0.79^{* * *}$ & $3.91 \pm 0.98^{* * *}$ & $2.58 \pm 0.8^{* * *}$ & $1.94 \pm 0.54$ & $22.33 \pm 1.46^{* * *}$ \\
200 & $3.62 \pm 1.01$ & $2.33 \pm 0.46$ & $1.61 \pm 0.42$ & $2.19 \pm 0.53$ & $1.41 \pm 0.4$ & $0.81 \pm 0.44^{* *}$ & $10.85 \pm 0.62$ \\
\hline
\end{tabular}

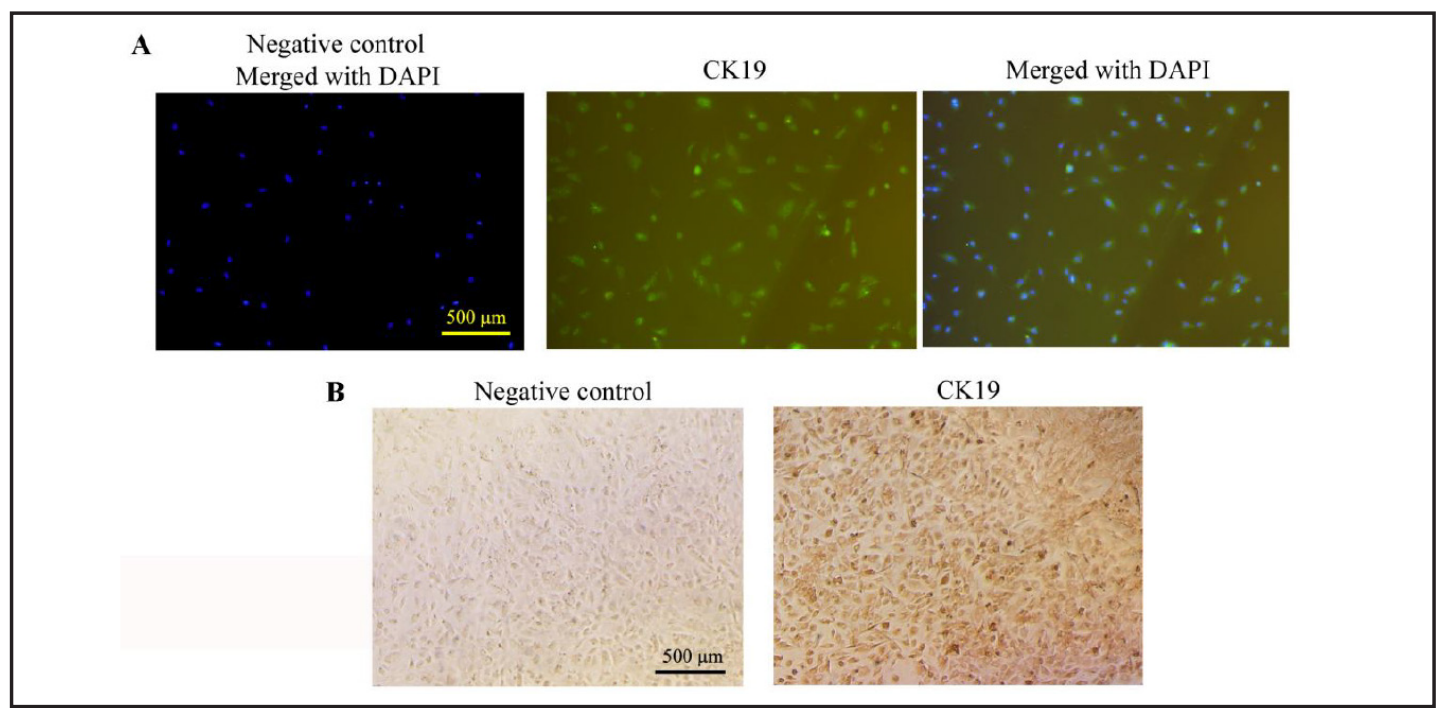

Fig. 1. Characterization of follicular ORS cells. ORS cells were prepared from the hair follicles of 4-month old American minks, and cultured in vitro. The third-generation ORS cells were characterized by (A) immunofluorescence staining (40× magnification) and (B) immunocytochemistry (40× magnification) for the expression of CK19. Negative control staining was performed by replacing anti-CK19 antibody with PBS during the incubation with primary antibody.

Instead, $200 \mathrm{ng} / \mathrm{ml} \mathrm{EGF} \mathrm{somehow} \mathrm{inhibited} \mathrm{ORS} \mathrm{growth} \mathrm{on} \mathrm{day} 6$. Thus, the results suggest that the growth-stimulatory effect of EGF on follicular ORS relied on the right concentration.

\section{EGF promotes proliferation and migration of ORS cells}

To investigate the effect of EGF on follicle growth, ORS cells were prepared from the hair follicles of mink dorsal skin and cultured in vitro. ORS cells were identified by the expression of CK 19 [13] (Fig. 1). ORS cells were treated with EGF at the concentration of $25 \mathrm{ng} / \mathrm{ml}, 50$ $\mathrm{ng} / \mathrm{ml}$ or $100 \mathrm{ng} / \mathrm{ml}$, and the proliferation of ORS cells was assessed by MTT assay. EGF of $50 \mathrm{ng} / \mathrm{ml}$ and $100 \mathrm{ng} / \mathrm{ml}$ significantly increased the proliferation rate of ORS cells over $48 \mathrm{~h}$, whereas $25 \mathrm{ng} / \mathrm{ml} \mathrm{EGF} \mathrm{had} \mathrm{little} \mathrm{effect} \mathrm{on} \mathrm{cell} \mathrm{proliferation} \mathrm{(Fig.} \mathrm{2a).} \mathrm{On} \mathrm{the} \mathrm{other} \mathrm{hand,} \mathrm{EGF}$ of $50 \mathrm{ng} / \mathrm{ml}$ and $100 \mathrm{ng} / \mathrm{ml}$, but not $25 \mathrm{ng} / \mathrm{ml}$, significantly enhanced the migration of ORS cells, and the effect of EGF on cell migration was comparable between $50 \mathrm{ng} / \mathrm{ml}$ and $100 \mathrm{ng} /$ $\mathrm{ml}$ (Fig. 2b).

To confirm the effect of EGF on the proliferation and migration of ORS cells, ORS cells were transfected with EGF overexpression plasmids or the empty vector. The levels of EGF mRNA and protein were markedly increased in the ORS cells with EGF overexpression $(p<$ 0.001 ; Fig. 3A-C). Moreover, Overexpression of EGF significantly accelerated the proliferation of ORS cells ( $p<0.05$; Fig. 3D), and also promoted cell migration $(p<0.001$; Fig. 3E). The effects of EGF overexpression are consistent with EGF treatment in the ORS cells. 


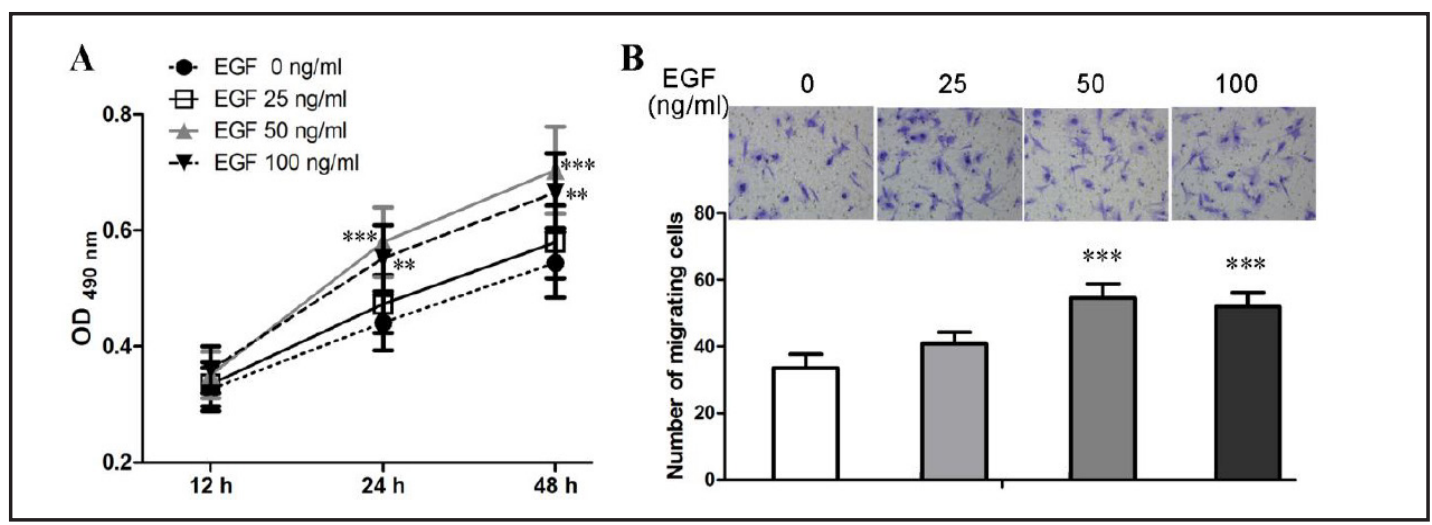

Fig. 2. EGF promotes proliferation and migration of ORS cells. (A) ORS cells were treated with $25 \mathrm{ng} / \mathrm{ml}, 50$ $\mathrm{ng} / \mathrm{ml}$ and $100 \mathrm{ng} / \mathrm{ml} \mathrm{EGF}$, and cell proliferation was measured by MTT assay. (B) The effect of EGF on the migration of ORS cells was assessed by matrigel-free transwell assay. The values are expressed as means \pm SD of three independent experiments. Compared with the untreated cells, ${ }^{* *} p<0.01,{ }^{* * *} p<0.001$.

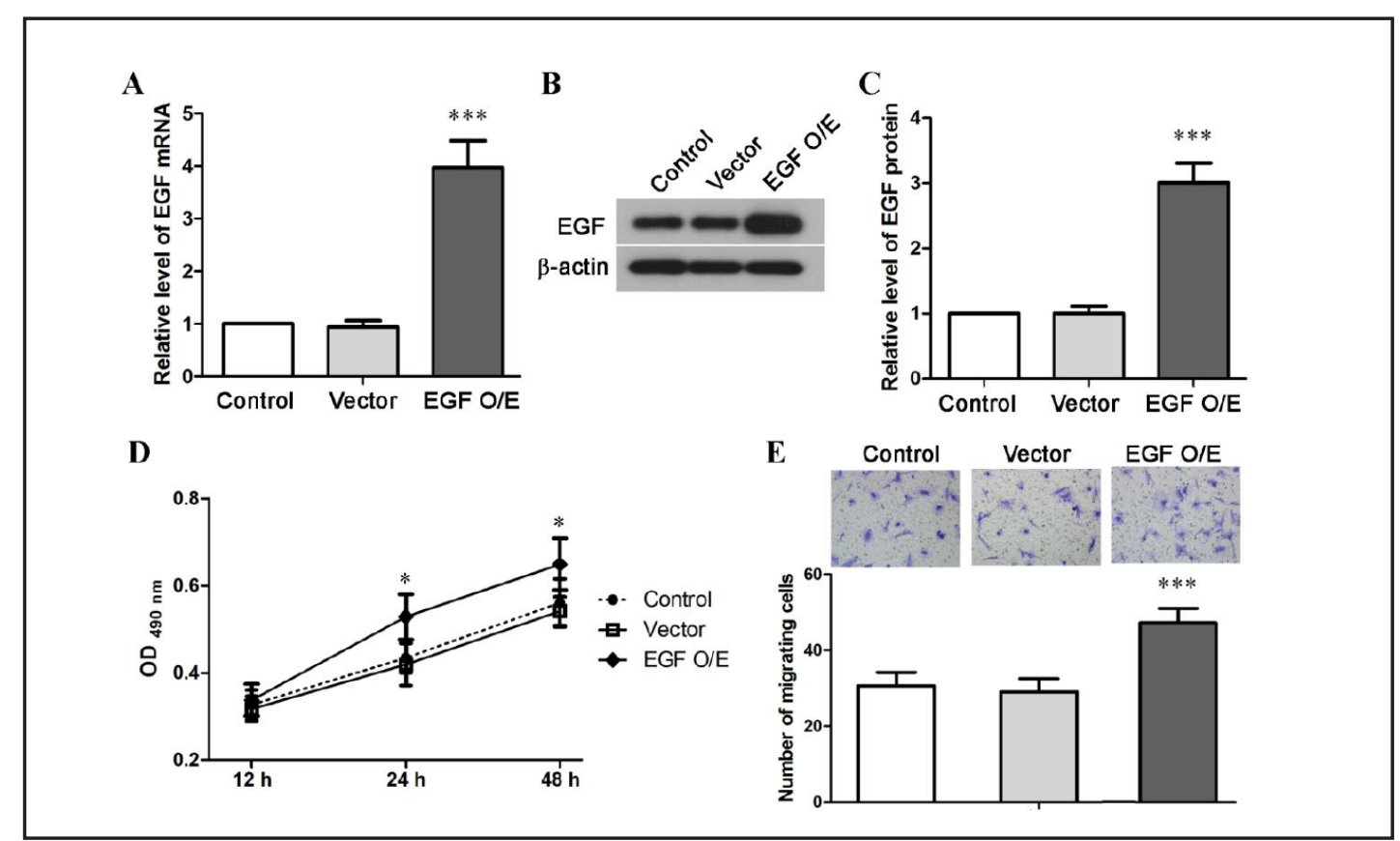

Fig. 3. Overexpression of EGF promotes proliferation and migration of ORS cells. ORS cells were transfected with EGF overexpression plasmids (EGF 0/E) or the empty vector. (A) The level of EGF mRNA was determined by real-time PCR. (B) The level of EGF protein was examined by Western blotting. (C) Densitometric analysis of the Western blots. (D) Proliferation of the EGF O/E-transfected ORS cells and the control cells was assessed by MTT assay. (E) Migration of the transfected ORS cells was measured by transwell assay. The values are expressed as means $\pm \mathrm{SD}$. Compared with the control cells, ${ }^{*} p<0.05,{ }^{* * *} p<0.001$.

\section{Prolonged EGF treatment or overexpression of EGF upregulates EGFR and SOX9}

EGF treatment of $48 \mathrm{~h}$ upregulated the expression of EGFR in ORS cells at both mRNA and protein levels, and the effect was prominent for $50 \mathrm{ng} / \mathrm{ml}$ and $100 \mathrm{ng} / \mathrm{ml} \mathrm{EGF}(p<0.001$; Fig. 4A, 4B). Similarly, the level of EGFR was significantly increased in EGF-transfected cells $48 \mathrm{~h}$ after transfection ( $p<0.001$; Fig. 4A, 4B). The upregulation of EGFR by prolonged EGF treatment or EGF overexpression is most likely attributed to the positive feedback loop between the ligand and the receptor. In the ORS cells, the expression of SOX9, an essential transcription factor for ORS differentiation [2], was also upregulated by EGF treatment or overexpression (Fig. 4C, 4D).

\section{KARGER}


Fig. 4. Prolonged EGF treatment and EGF overexpression upregulates the expression of EGFR and SOX9. (A) The mRNA and (B) protein levels of EGF in the ORS cells that were treated with the indicated concentration of EGF or transfected with EGF 0/E plasmids. (C) The mRNA and (D) protein levels of SOX9 in the ORS cells with EGF treatment or EGF overexpression. The values are expressed as means \pm SD of three independent experiments. Compared with the control cells, * $p<0.05$, ** $p<0.01$, *** $p<0.001$.

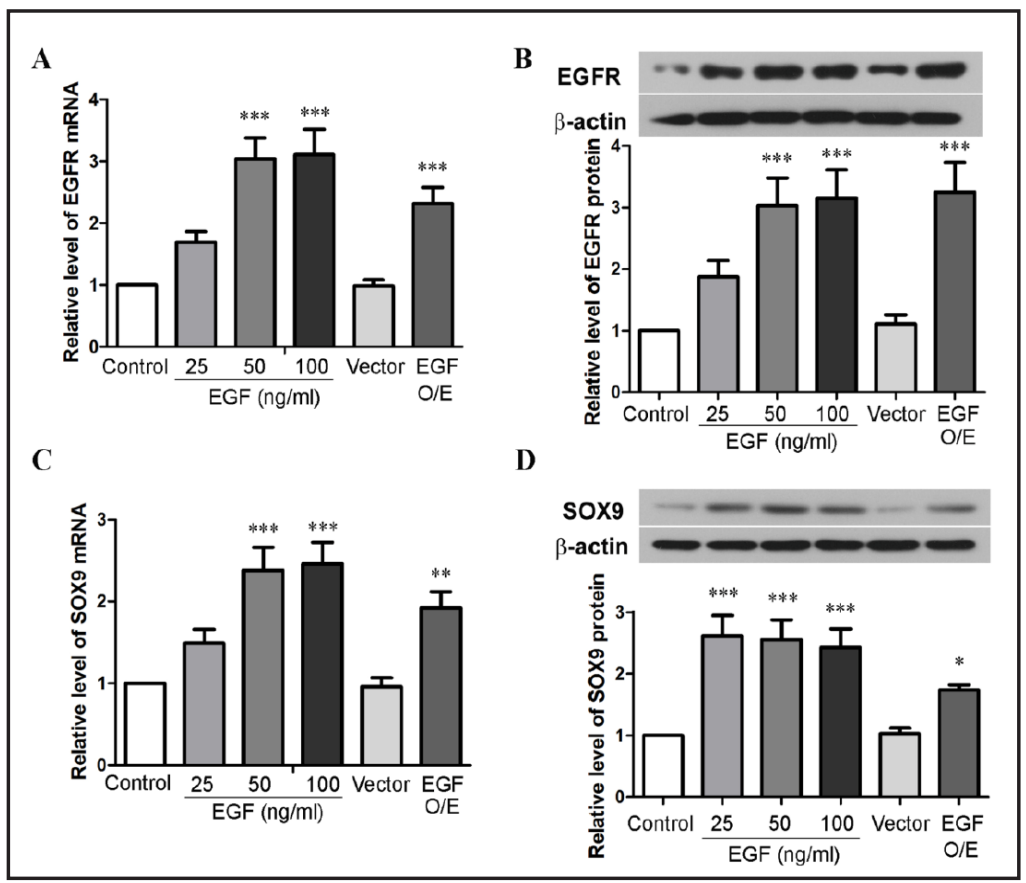

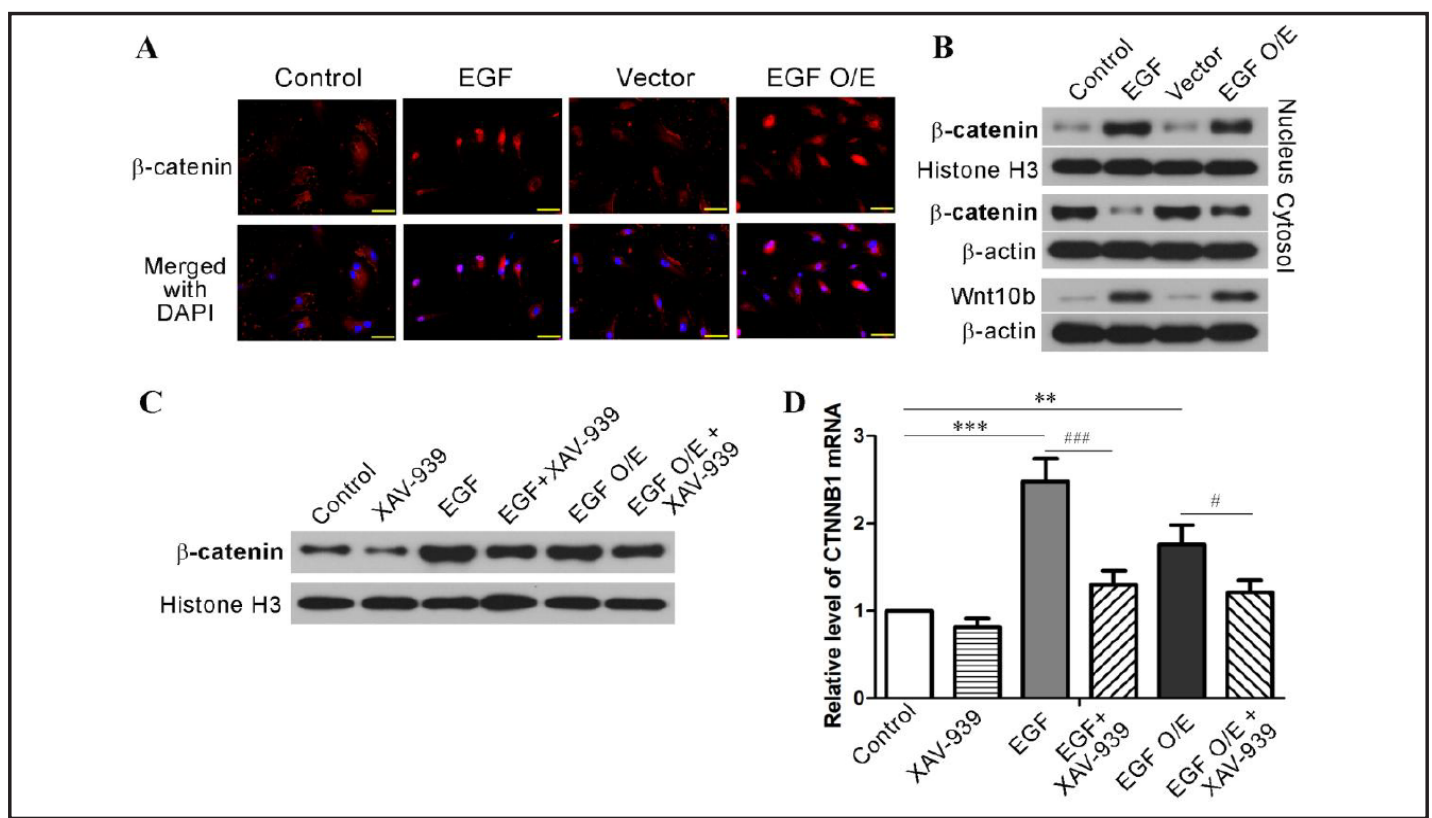

Fig. 5. XAV-939 inhibits EGF-induced activation of Wnt/ $\beta$-catenin signaling pathway. (A) Nuclear translocation of $\beta$-catenin in the ORS cells with EGF treatment or overexpression of EGF was assessed by immunofluorescent staining $(400 \times$ magnification, scale $=50 \mu \mathrm{m})$. (B) Western blot analysis was performed to examine the levels of nuclear and cytosolic $\beta$-catenin, as well as the expression of Wnt10b in the ORS cells. (C) The level of $\beta$-catenin in the nucleus of ORS cells with EGF stimulation and/or XAV-939 treatment was examined by Western blotting. (D) Transcription of $\beta$-catenin in the ORS cells with EGF stimulation and/or XAV-939 treatment was measured by real-time PCR. The values are expressed as means \pm SD of three independent experiments. Compared with the control cells, ${ }^{* *} p<0.01$, ${ }^{* * *} p<0.001$; with versus without XAV-939, ${ }^{*} p<$ $0.05,{ }^{\# \#} p<0.01$.

\section{EGF activates Wnt/ $\beta$-catenin pathway}

In the ORS cells, EGF treatment and overexpression of EGF induced nuclear translocation of $\beta$-catenin (Fig. 5A, 5B), which is a hallmark of active Wnt signaling [14]. Moreover, 
Fig. 6. Inhibition of Wnt/ $\beta$-catenin signaling suppresses proliferation and migration of ORS cell. (A) MTT assay were performed to assess the proliferation of the ORS cells with EGF stimulation and/or XAV-939 treatment. (B) Cell migration was measured by transwell assay. The values are expressed as means \pm SD of three independent experiments; ${ }^{* * *} p<$ 0.001 .

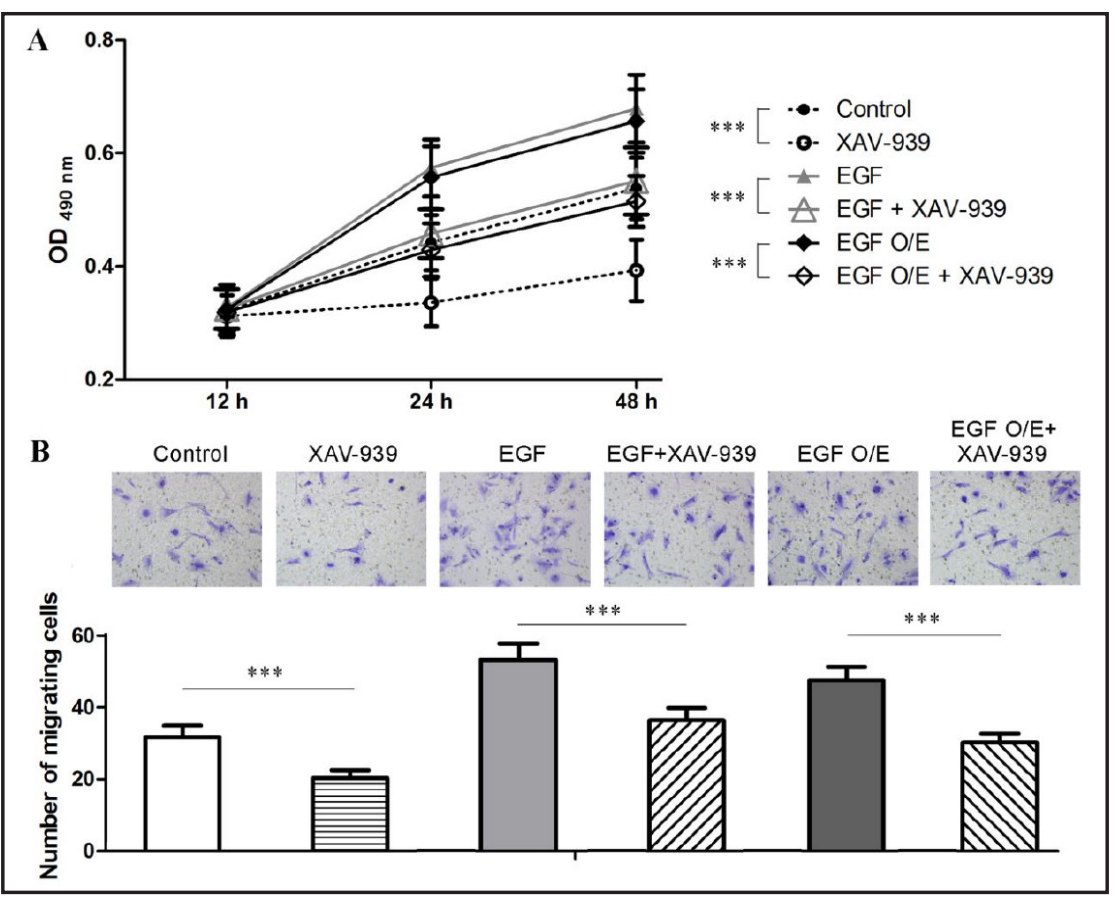

prolonged EGF stimulation also upregulated the expression of Wnt10b in the ORS cells (Fig. 5B). Next, we blocked $\beta$-catenin pathway using XAV-939, a specific inhibitor of Wnt/ $\beta$-catenin signaling by promoting the degradation of $\beta$-catenin [15]. Treatment with XAV-939 reduced the basal level and EGF-stimulated elevation of $\beta$-catenin in the nucleus of ORS cells (Fig. 5C). Meanwhile, prolonged EGF treatment or EGF overexpression increased the mRNA level of CTNNB1, which encodes $\beta$-catenin, and such EGF-upregulated transcription of CTNNB1 was inhibited by XAV-939 (Fig. 5D).

\section{EGF promotes proliferation and migration of ORS cells via Wht/ $\beta$-catenin signaling}

To investigate the role of the Wnt/ $\beta$-catenin signaling pathway in mediating EGFstimulated proliferation and migration of ORS cells, the cells were treated with XAV-939 and analyzed for the proliferation and migration ability. As shown in Fig. 6A, inhibition of Wnt/ $\beta$ catenin signaling by XAV-939 significantly decreased the basal proliferation rate and EGFstimulated proliferation of ORS cells $(p<0.001)$. Moreover, XAV-939 significantly reduced the migration ability of ORS cells with or without EGF stimulation $(p<0.001$; Fig. 6B).

EGF upregulates the expression of follicle-regulatory genes via Wnt/ $\beta$-catenin pathway

We further examined a group of genes that have been implicated in the regulatory network of hair follicle development and growth, such as Survivin [16], Msx2 [17] and SGK3 [18]. Real-time PCR and Western blot analysis showed that ORS cells normally expressed Survivin, Msx2 and SGK3, and the expression of these three genes was significantly elevated by EGF treatment and overexpression (Fig. 7). By contrast, EGF-induced upregulation of Survivin, Msx2 and SGK3 was inhibited by XAV-939.

\section{Discussion}

EGF acts as a guardian of epidermal renewal and integrity, and it also plays an important role in the growth of hair and hair follicles [19]. Contradictory effects of EGF on the growth of hair follicles have been reported $[19,20]$, and it is presumably attributed to the discrepancies in EGF concentration, the stage of hair cycle and the effector cells. In this study, $2 \mathrm{ng} / \mathrm{ml}$ and $20 \mathrm{ng} / \mathrm{ml}$ EGF displayed a remarkable stimulatory effect on the growth of 


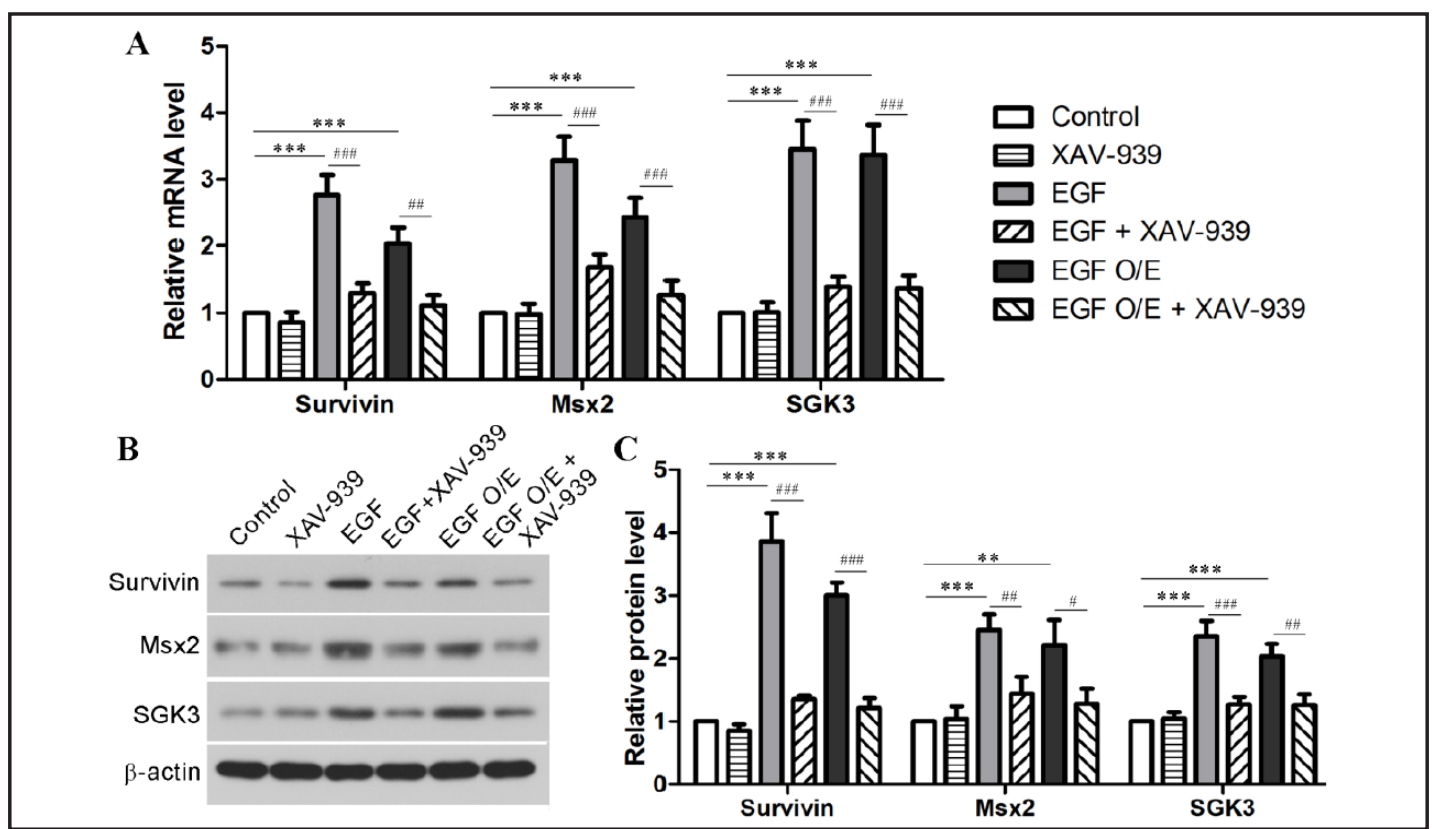

Fig. 7. EGF upregulates the expression of follicle-regulatory genes via Wnt/ $\beta$-catenin signaling pathway. (A) The mRNA and $(B, C)$ the protein levels of Survivin, Msx2 and SGK3 in the ORS cells with EGF treatment/ overexpression and/or XAV-939 treatment. The values are expressed as means \pm SD of three independent experiments. Compared with the control cells, ${ }^{* *} p<0.01$, ${ }^{* * *} p<0.001$; with versus without XAV-939, ${ }^{*} p<$ $0.05,{ }^{\# \#} p<0.01,{ }^{\# \# \#} p<0.01$.

the ORS compartment in vitro, whereas the ORS did not respond to a higher concentration of EGF regarding to growth but was somehow inhibited by the high-dose EGF. The ORS forms the outermost epithelial layer of the hair follicle and represents a direct continuation of the basal layer of the epidermis. EGF was previously demonstrated to promote keratinization of ORS cells [21], and it induces epidermal differentiation at the expense of hair follicle fate [22]. Thus, high concentrations of EGF may promote differentiation of ORS cells, rather than proliferation. As such, the concentration of EGF is critical for its function in the ORS in terms of proliferation versus differentiation.

Proliferation and migration of the ORS cells contribute to the outgrowth of the ORS. In the present study, EGF treatment or overexpression of EGF accelerated the proliferation of the ORS cells. The mitogenic effect of EGF on the cultured ORS cells is consistent with previous studies $[7,23]$. In addition, EGF also promoted the migration of ORS cells. Previous studies have demonstrated that inhibition of EGFR results in decreases in the growth and migration rates of keratinocytes [19]. Here, we show that EGF also signals the ORS cells to devote the energy to growth and migration, for the elongation of the ORS as well as the hair follicle.

In the present study, prolonged EGF treatment or EGF overexpression upregulated the expression of EGFR in the ORS cells. This is most likely attributed to the positive feedback loop between the ligand and the receptor. In addition, long-term EGF stimulation also enhanced the expression of SOX9, an essential transcription factor for ORS differentiation [2], suggesting that EGF may play a role in the fate determination of ORS through SOX9.

Wnt/ $\beta$-catenin signaling is critical for the development and regeneration of hair follicles $[9,10]$. Wnt signaling is mediated by stabilization and translocation of $\beta$-catenin to the nucleus where it binds TCF/Lef to activate the transcription of Wnt target genes [24]. In the present study, EGF induced nuclear translocation of $\beta$-catenin and also augmented the expression of $\beta$-catenin and Wnt10b. Moreover, EGF-induced upregulation of $\beta$-catenin was inhibited by XAV-939. These results suggest that EGF augments the $\beta$-catenin pathway through a positive feedback loop, and Wnt10b is likely to be involved in EGF- $\beta$-catenin amplification loop in the

\section{KARGER}




\section{Cellular Physiology Cell Physiol Biochem 2016;39:360-370 \begin{tabular}{l|l} 
DOI: 10.1159/000445630 & O 2016 The Author(s). Published by S. Karger AG, Basel \\
www.karger.com/cpb
\end{tabular} \\ Zhang et al.: EGF Promotes ORS Growth and Migration via Wnt/ß-Catenin}

ORS cells. Wnt10b was previously demonstrated to promote the growth of hair follicles via the canonical Wnt/ $\beta$-catenin signaling pathway [25]. In our study, inhibition of $\beta$-catenin signaling by XAV-939 attenuated basal and EGF-stimulated proliferation and migration of ORS cells, implying that $\beta$-catenin signaling is required for the proliferation and migration of ORS cells. In addition, by upregulating Wnt10b, EGF stimulates the proliferation and migration of ORS cells through the canonical Wnt/ $\beta$-catenin signaling pathway.

Survivin, Msx2 and SGK3 are implicated in the development, morphogenesis and cyclic growth of hair follicles [16-18]. Wnt/ $\beta$-catenin signaling pathway has been proposed to mediate SGK3-dependent regulation of hair follicle development [26] and modulate Survivin expression during adult neurogenesis [27]. In this study, EGF upregulated the expression of Survivin, Msx2 and SGK3 in the ORS cells, which was inhibited by XAV-939, suggesting that Wnt/ $\beta$-catenin signaling is required for EGF-stimulated expression of Survivin, Msx2 and SGK3 in the ORS cells. However, the impact of EGF-modulated expression of these follicleregulatory genes on follicle development or growth remains to be further elucidated in future studies.

In conclusion, EGF can promote growth of the ORS compartment of mink hair follicles in vitro, and enhance proliferation and migration of the ORS cells via activation of the Wnt/ $\beta$ catenin signaling pathway. Moreover, Wnt/ $\beta$-catenin signaling also mediates EGF-induced expression of several follicle-regulatory genes in the ORS cells.

\section{Acknowledgements}

This study was supported by grants from the National Natural Science Foundation of China (No. 31301956) and the Science and Technology Development Project of Jilin Province (No. 20140520178JH).

\section{Disclosure Statement}

The authors declare that they have no conflict of interest.

\section{References}

1 Paus R, Cotsarelis G: The biology of hair follicles. N Engl J Med 1999;341:491-497.

2 Vidal VP, Chaboissier MC, Lutzkendorf S, Cotsarelis G, Mill P, Hui CC, Ortonne N, Ortonne JP, Schedl A: Sox9 is essential for outer root sheath differentiation and the formation of the hair stem cell compartment. Curr Biol 2005;15:1340-1351.

3 Moore GP, Du Cros DL, Isaacs K, Pisansarakit P, Wynn PC: Hair growth induction: Roles of growth factors. Ann N Y Acad Sci 1991;642:308-325.

4 Green MR, Couchman JR: Distribution of epidermal growth factor receptors in rat tissues during embryonic skin development, hair formation, and the adult hair growth cycle. J Invest Dermatol 1984;83:118-123.

5 Wynn PC, Brown G, Moore GP: Characterization and distribution of epidermal growth factor receptors in the skin and wool follicles of the sheep fetus during development. Domest Anim Endocrinol 1995;12:269281.

6 Katsuoka K, Schell H, Hornstein OP, Wessel B: Epidermal growth factor and fibroblast growth factor accelerate proliferation of human hair bulb papilla cells and root sheath fibroblasts cultured in vitro. Br J Dermatol 1987;116:464-465.

7 Bond JJ, Wynn PC, Moore GP: Effects of epidermal growth factor and transforming growth factor alpha on the function of wool follicles in culture. Arch Dermatol Res 1996;288:373-382. 


\section{Cellular Physiology Cell Physiol Biochem 2016;39:360-370 \begin{tabular}{ll|l} 
DOI: 10.1159/000445630 & $\begin{array}{l}\text { O 2016 The Author(s). Published by S. Karger AG, Basel } \\
\text { www.karger.com/cpb }\end{array}$
\end{tabular} \\ Zhang et al.: EGF Promotes ORS Growth and Migration via Wnt/ $\beta$-Catenin}

8 Rishikaysh P, Dev K, Diaz D, Qureshi WM, Filip S, Mokry J: Signaling involved in hair follicle morphogenesis and development. Int J Mol Sci 2014;15:1647-1670.

9 Huelsken J, Vogel R, Erdmann B, Cotsarelis G, Birchmeier W: Beta-catenin controls hair follicle morphogenesis and stem cell differentiation in the skin. Cell 2001;105:533-545.

10 Andl T, Reddy ST, Gaddapara T, Millar SE: Wnt signals are required for the initiation of hair follicle development. Dev Cell 2002;2:643-653.

11 Zhang Y, Tomann P, Andl T, Gallant NM, Huelsken J, Jerchow B, Birchmeier W, Paus R, Piccolo S, Mikkola ML, Morrisey EE, Overbeek PA, Scheidereit C, Millar SE, Schmidt-Ullrich R: Reciprocal requirements for eda/ edar/nf-kappab and wnt/beta-catenin signaling pathways in hair follicle induction. Dev Cell 2009;17:4961.

12 Cui Z, Hu Y, Wang H, Zeng Y, Dong B, Zhu H, Dong Z, Liu Z: Establishment and characterization of outer root sheath (ors) cell line from jining grey goat. Biotechnol Lett 2012;34:433-440.

13 Schirren CG, Burgdorf WH, Sander CA, Plewig G: Fetal and adult hair follicle. An immunohistochemical study of anticytokeratin antibodies in formalin-fixed and paraffin-embedded tissue. Am J Dermatopathol 1997;19:335-340.

14 Clevers H, Nusse R: Wnt/beta-catenin signaling and disease. Cell 2012;149:1192-1205.

15 Huang SM, Mishina YM, Liu S, Cheung A, Stegmeier F, Michaud GA, Charlat O, Wiellette E, Zhang Y, Wiessner S, Hild M, Shi X, Wilson CJ, Mickanin C, Myer V, Fazal A, Tomlinson R, Serluca F, Shao W, Cheng H, Shultz M, Rau C, Schirle M, Schlegl J, Ghidelli S, Fawell S, Lu C, Curtis D, Kirschner MW, Lengauer C, Finan PM, Tallarico JA, Bouwmeester T, Porter JA, Bauer A, Cong F: Tankyrase inhibition stabilizes axin and antagonizes wnt signalling. Nature 2009;461:614-620.

16 Botchkareva NV, Kahn M, Ahluwalia G, Shander D: Survivin in the human hair follicle. J Invest Dermatol 2007;127:479-482.

17 Ma L, Liu J, Wu T, Plikus M, Jiang TX, Bi Q Liu YH, Muller-Rover S, Peters H, Sundberg JP, Maxson R, Maas RL, Chuong CM: 'Cyclic alopecia' in msx2 mutants: Defects in hair cycling and hair shaft differentiation. Development 2003;130:379-389.

18 Mauro TM, McCormick JA, Wang J, Boini KM, Ray L, Monks B, Birnbaum MJ, Lang F, Pearce D: Akt2 and sgk3 are both determinants of postnatal hair follicle development. FASEB J 2009;23:3193-3202.

19 Lacouture ME: Mechanisms of cutaneous toxicities to egfr inhibitors. Nat Rev Cancer 2006;6:803-812.

20 Moore GP, Panaretto BA, Carter NB: Epidermal hyperplasia and wool follicle regression in sheep infused with epidermal growth factor. J Invest Dermatol 1985;84:172-175.

21 Niderla-Bielinska J, Jankowska-Steifer E, Moskalewski S: Keratinization of outer root sheath cells is prevented by contact with inner root sheath of rat hair follicles. Arch Dermatol Res 2009;301:337-345.

22 Richardson GD, Bazzi H, Fantauzzo KA, Waters JM, Crawford H, Hynd P, Christiano AM, Jahoda CA: Kgf and egf signalling block hair follicle induction and promote interfollicular epidermal fate in developing mouse skin. Development 2009;136:2153-2164.

23 Katsuoka K, Schell H, Wessel B, Hornstein OP: Effects of epidermal growth factor, fibroblast growth factor, minoxidil and hydrocortisone on growth kinetics in human hair bulb papilla cells and root sheath fibroblasts cultured in vitro. Arch Dermatol Res 1987;279:247-250.

24 van Amerongen R, Nusse R: Towards an integrated view of wnt signaling in development. Development 2009;136:3205-3214.

25 Li YH, Zhang K, Ye JX, Lian XH, Yang T: Wnt10b promotes growth of hair follicles via a canonical wnt signalling pathway. Clin Exp Dermatol 2011;36:534-540.

26 Okada T, Ishii Y, Masujin K, Yasoshima A, Matsuda J, Ogura A, Nakayama H, Kunieda T, Doi K: The critical roles of serum/glucocorticoid-regulated kinase 3 ( $\mathrm{sgk} 3$ ) in the hair follicle morphogenesis and homeostasis: The allelic difference provides novel insights into hair follicle biology. Am J Pathol 2006;168:1119-1133.

27 Miranda CJ, Braun L, Jiang Y, Hester ME, Zhang L, Riolo M, Wang H, Rao M, Altura RA, Kaspar BK: Aging brain microenvironment decreases hippocampal neurogenesis through wnt-mediated survivin signaling. Aging Cell 2012;11:542-552. 